\title{
Novel synthesis of pseudopeptides bearing a difluoromethyl group by Ugi reaction and desulfanylation
}

\author{
Jingjing Wu, Hui Li and Song Cao*
}

\author{
Full Research Paper \\ Address: \\ Shanghai Key Laboratory of Chemical Biology, School of Pharmacy, \\ East China University of Science and Technology, Shanghai 200237, \\ China \\ Email: \\ Song Cao* - scao@ecust.edu.cn \\ * Corresponding author \\ Keywords: \\ difluoromethyl functionality; gem-difluoromethylene-containing acid; \\ pseudopeptides; reductive cleavage; Ugi reaction
}

Beilstein J. Org. Chem. 2011, 7, 1070-1074.

doi:10.3762/bjoc. 7.123

Received: 07 April 2011

Accepted: 12 July 2011

Published: 08 August 2011

This article is part of the Thematic Series "Multicomponent reactions".

Guest Editor: T. J. J. Müller

(c) 2011 Wu et al; licensee Beilstein-Institut. License and terms: see end of document.

\begin{abstract}
Thirteen difluoromethyl-containing pseudopeptides were synthesized by Ugi reaction using the novel building block 2,2-difluoro-2(phenylthio)acetic acid (2) as one component, followed by removal of the phenylsulfanyl protecting group in the presence of tributyltin hydride and azobisisobutyronitrile.
\end{abstract}

\section{Introduction}

Fluorinated amino acids and pseudopeptides have increasingly attracted attention in recent years [1-5]. The selective incorporation of fluorine-containing groups, such as trifluoromethyl, difluoromethyl and difluoromethylene, into peptides or peptidomimetics often drastically alters the chemical, physical, and biological properties of the parent compounds [6-9]. Nowadays, difluoromethyl-containing compounds are increasingly being applied in pharmaceuticals and agrochemicals [10-12]. It is reported that difluoromethyl functionality $\left(\mathrm{CF}_{2} \mathrm{H}\right)$ is isosteric and isopolar to the hydroxyl group and can behave as a hydrogen donor through hydrogen bonding [13].

However, to date, most fluorine-containing peptide modifications involve the introduction of trifluoromethyl or difluoro- methylene into molecules [14-18]. Only a few examples have been reported of the preparation and bioassay of pseudopeptides and peptidomimetics bearing difluoromethyl groups. For example, compound $\mathbf{I}$ can act as bradykinin B1 antagonist or inverse agonist and can be used in the prevention of inflammation and pain [19]. Compound II is an inhibitor of microsomal triglyceride transfer protein (MTP) and useful for the treatment of obesity and atherosclerosis (Figure 1) [20].

Among the protocols for the preparation of pseudopeptide derivatives, the Ugi four-component reaction offers significant advantages over conventional linear-step synthesis [21]. Various fluorinated building blocks have been used in the Ugi four-component reaction to construct a fluorinated compound 
<smiles>CCOc1c(Cl)cc(Cl)cc1-c1cnc(C(C)NC(=O)C2(NC(=O)C(F)(F)F)CC2)c(F)c1</smiles>

I<smiles>O=C(Nc1ccc(CNC(=O)C(NC(=O)C(F)(F)F)c2ccccc2)cc1Cl)c1ccccc1-c1ccc(C(F)(F)F)cc1</smiles>

II

Figure 1: Two examples of bioactive pseudopeptides bearing a $\mathrm{CF}_{2} \mathrm{H}$ group.

library [22-25]. Our group has always been interested in developing efficient methods for the preparation of difluoromethylcontaining compounds through multicomponent reactions [2630]. Recently, we reported a novel and general strategy for the construction of a difluoromethyl compound library, and we further illustrated this strategy by application to the synthesis of $\mathrm{CF}_{2} \mathrm{H}$-bearing pseudopeptides and 1,2,3-triazoles through Ugi and click reaction, respectively [27,30]. In continuation of our interest in the synthesis of diverse difluoromethyl-containing pseudopeptides, we herein report a novel and efficient synthesis of difluoromethyl-containing pseudopeptides through Ugi reaction, with gem-difluoromethylene-containing acid as a key component, followed by reductive cleavage of the phenylsulfanyl group (Scheme 1).

\section{Results and Discussion}

For the purpose of screening novel bioactive compounds, we recently prepared a variety of diverse difluoromethyl-containing pseudopeptides. In our initial experiments, we tried to use difluoroacetic acid as one component to undergo Ugi reaction to prepare difluoromethyl-containing pseudopeptides. Unfortunately, the anticipated difluoromethyl-containing product 4a was not obtained (Scheme 2). Although there are a few examples of acetic acid and trifluoroacetic acid acting as substrates in an Ugi reaction [24,31], up to now, no literature was found concerning the use of difluoroacetic acid as one of the components in the Ugi reaction. For a comparative study, acetic acid and trifluoroacetic acid served as the substrates for the Ugi reaction under the same reaction conditions as those used for the difluoroacetic acid, and the results indicated that the reaction proceeded efficiently regardless of reaction conditions, and the Ugi products (5 and 6) were obtained in good yields. The hydrogen atom next to the $\mathrm{CF}_{2}$ group seems to influence the formation of Ugi product.

In previous studies, we developed a synthetic methodology to prepare functionalized small molecules having a $\mathrm{CF}_{2} \mathrm{H}$ group [27]. In this work, we first synthesized a protected difluorocontaining building block, 2,2-difluoro-2-(phenylthio)acetic acid (2). The synthesis of compound 2 is illustrated in Scheme 3. The ethyl 2,2-difluoro-2-(phenylthio)acetate (1) was readily prepared by the reaction of ethyl bromodifluoroacetate and thiophenol according to the known procedure [32]. The novel difluorinated acid $\mathbf{2}$ was obtained by hydrolysis of the ester under basic condition in nearly quantitative yield.

After successful synthesis of the protected functionalized $\mathrm{CF}_{2}$ building block 2 , we tried to use it as one of the components in the preparations of the difluoromethylene-containing pseudopeptides by Ugi reaction. Indeed, the reaction of aniline,<smiles>[R][CH-][O+]=[N+][C-]=[N+][R]</smiles><smiles>[R3]NC(=O)C([R])N([R])C(=O)C(F)(F)Sc1ccccc1</smiles>

3a-m

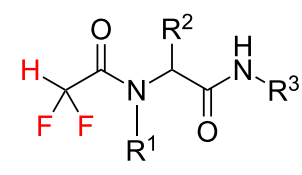

4a-m 


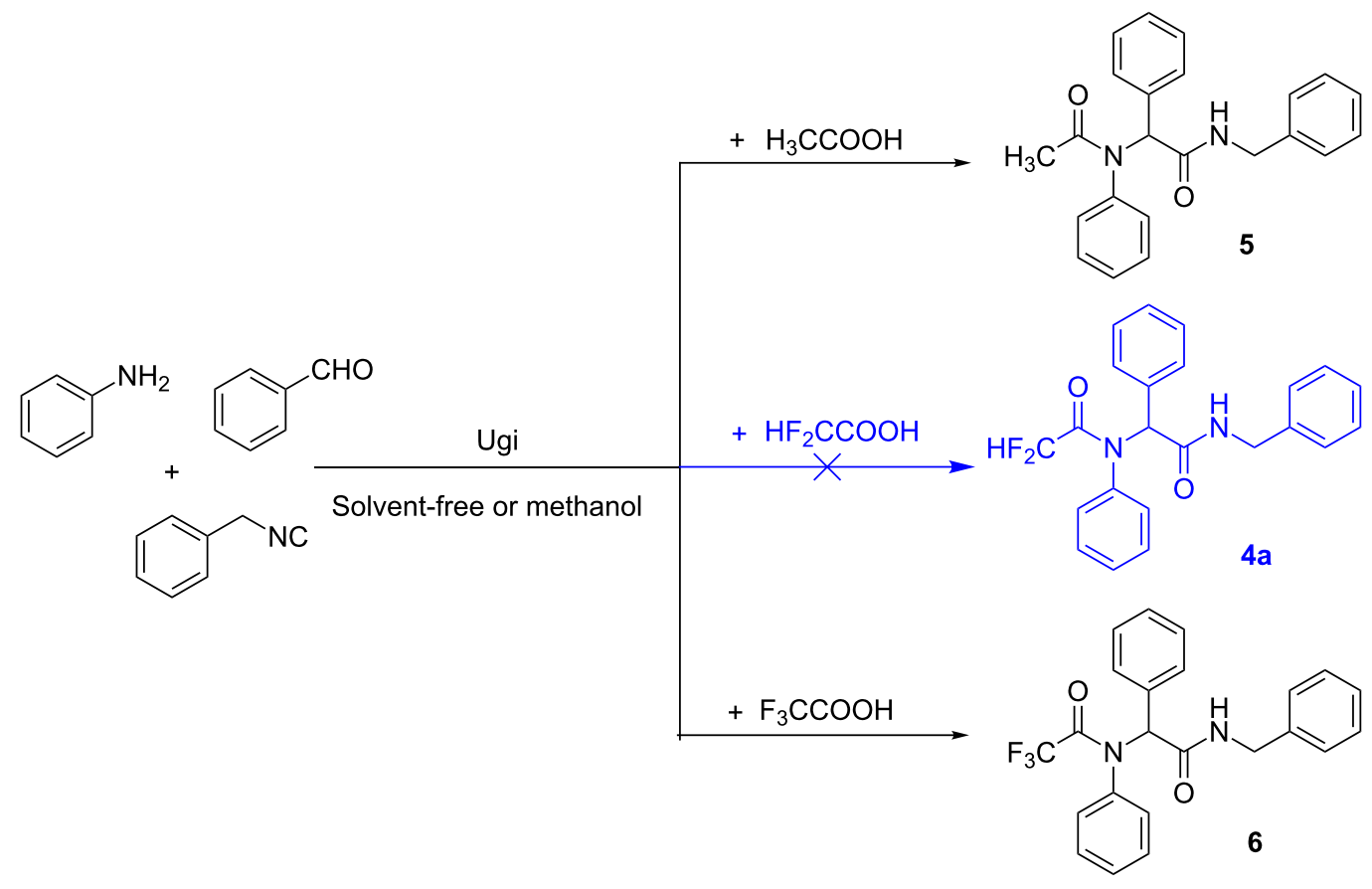

Scheme 2: The Ugi reaction of aniline, benzaldehyde, (isocyanomethyl)benzene with acetic acid, difluoroacetic acid and trifluoroacetic acid in methanol or under solvent-free conditions.

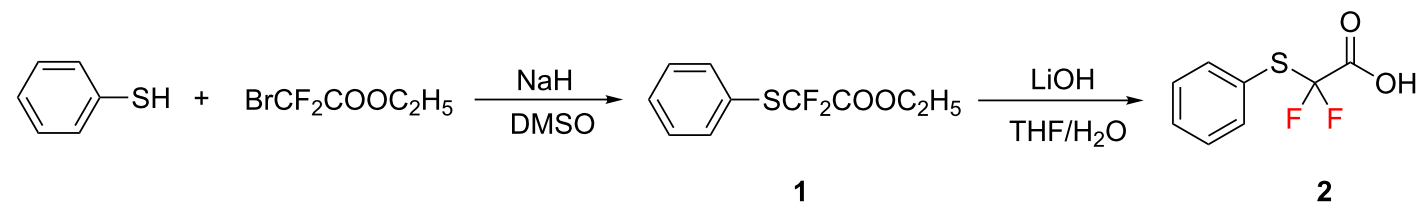

Scheme 3: Synthesis of 2,2-difluoro-2-(phenylthio)acetic acid (2).

benzaldehyde, (isocyanomethyl)benzene with $\mathbf{2}$ proceeded efficiently under solvent-free conditions. Finally, we removed the protecting group ( $\mathrm{PhS}$ ) with $\mathrm{Bu}_{3} \mathrm{SnH} / \mathrm{AIBN}$ according to our previous research, and the desired difluoromethyl-containing pseudopeptide was successfully obtained [27].

To demonstrate the scope of the method, several different substituted anilines, substituted benzaldehydes, isocyanides and this novel difluorinated building block $\mathbf{2}$ were subjected to Ugi reaction under solvent-free conditions, followed by reductive cleavage of the phenylsulfanyl group. It was found that both Ugi reaction and desulfanylation proceeded smoothly for all substrates used to give the corresponding difluoromethylenecontaining and difluoromethyl-containing pseudopeptides $(\mathbf{3 a}-\mathbf{m}$ and $\mathbf{4 a}-\mathbf{m})$ in good yields (Table 1).

\section{Conclusion}

In summary, we have developed a novel and efficient protocol for the synthesis of $\mathrm{CF}_{2} \mathrm{H}$-containing pseudopeptides by Ugi reaction of substituted anilines, benzaldehyde, isocyanides and the novel building block 2,2-difluoro-2-(phenylthio)acetic acid (2), followed by the cleavage of the phenylsulfanyl group.

\section{Experimental \\ General}

All reagents were of analytic grade, obtained from commercial suppliers and were used without further purification. Melting points were measured in an open capillary using Büchi melting point B-540 apparatus and are uncorrected. ${ }^{1} \mathrm{H}$ NMR and ${ }^{13} \mathrm{C}$ NMR spectra were recorded on a Bruker AM-400 spectrometer (400 MHz and $100 \mathrm{MHz}$, respectively) using TMS as 
Table 1: Synthesis of difluoromethylene-containing pseudopeptides (3a-m) and difluoromethyl-containing pseudopeptides (4a-m).<smiles>[R]NC(=O)C([R])N([R])C(=O)C(F)(F)Sc1ccccc1</smiles>

$3 a-m$<smiles>[R3]NC(=O)C([R])N([R])C(=O)C([2H])(F)F</smiles>

4a-m

\begin{tabular}{|c|c|c|c|c|c|}
\hline Entry & $\mathrm{R}^{1}$ & $\mathrm{R}^{2}$ & $\mathrm{R}^{3}$ & $\begin{array}{l}3 \\
\text { Yield }(\%)^{a}\end{array}$ & $\begin{array}{l}4 \\
\text { Yield }(\%)^{a}\end{array}$ \\
\hline a & $\mathrm{Ph}$ & $\mathrm{Ph}$ & $\mathrm{Bn}$ & 82 & 75 \\
\hline$b$ & 2-MePh & $\mathrm{Ph}$ & $\mathrm{Bn}$ & 78 & 68 \\
\hline c & 2-MePh & 4-MePh & $\mathrm{Bn}$ & 75 & 74 \\
\hline$d$ & 4-MeOPh & $\mathrm{Ph}$ & $\mathrm{Bn}$ & 79 & 75 \\
\hline e & $\mathrm{Ph}$ & 4-MeOPh & $\mathrm{Bn}$ & 78 & 70 \\
\hline$f$ & 2-MePh & 4-MeOPh & $\mathrm{Bn}$ & 74 & 67 \\
\hline$g$ & 4-MePh & 4-MeOPh & $\mathrm{Bn}$ & 72 & 78 \\
\hline $\mathrm{h}$ & 4-FPh & 4-MeOPh & $\mathrm{Bn}$ & 70 & 71 \\
\hline i & $\mathrm{Ph}$ & 4-FPh & $\mathrm{Bn}$ & 77 & 75 \\
\hline j & 2-MePh & 4-FPh & $\mathrm{Bn}$ & 70 & 69 \\
\hline $\mathrm{k}$ & 4-MeOPh & 4-FPh & $\mathrm{Bn}$ & 72 & 74 \\
\hline I & $\mathrm{Ph}$ & $\mathrm{Ph}$ & $\mathrm{Ph}$ & 68 & 66 \\
\hline $\mathrm{m}$ & $\mathrm{Ph}$ & 4-MeOPh & $\mathrm{Ph}$ & 66 & 60 \\
\hline
\end{tabular}

alsolated yield.

internal standard. The ${ }^{19} \mathrm{~F}$ NMR were obtained using a Bruker AM-400 spectrometer (376 MHz) and the ${ }^{19} \mathrm{~F}$ NMR were measured with external $\mathrm{CF}_{3} \mathrm{CO}_{2} \mathrm{H}$ as standard. Gas chromatography-mass spectra (GC-MS) were recorded on HP 5973 MSD with 6890 GC. High resolution mass spectra (HRMS) were recorded under electron impact conditions using a MicroMass GCT CA 055 instrument and recorded on a MicroMass LCTTM spectrometer. Column chromatography was carried out with Merck 60 (230-400 mesh) silica gel.

\section{General procedure for compounds 3a-m}

To a stirred amine $(1 \mathrm{mmol})$, the aldehyde $(1 \mathrm{mmol})$ was added in portions for about $5 \mathrm{~min}$. The mixture was stirred for $30 \mathrm{~min}$ at rt. Then, the reaction mixture was heated to $60{ }^{\circ} \mathrm{C}$, and isocyanide (1 mmol) and 2,2-difluoro-2-(phenylthio)acetic acid (2) $(1 \mathrm{mmol})$ were added. Stirring was continued at $60{ }^{\circ} \mathrm{C}$ for $1 \mathrm{~h}$ (TLC). The crude residue was purified by chromatography to give the desired products 3 .

\section{General procedure for compounds $4 a-m$}

$\mathrm{Bu}_{3} \mathrm{SnH}$ (0.58 g, $\left.2 \mathrm{mmol}\right)$ was added under argon atmosphere to a solution of $3(1 \mathrm{mmol})$ in dry toluene $(3 \mathrm{~mL})$. Deoxygenation was continued for $5 \mathrm{~min}$. Azobisisobutyronitrile (AIBN) $(0.02 \mathrm{~g}, 0.1 \mathrm{mmol})$ was added and the solution was heated at reflux for $9 \mathrm{~h}$ (TLC). The mixture was concentrated under reduced pressure and the residue was dissolved in EtOAc ( $5 \mathrm{~mL}$ ). The solution was stirred with $\mathrm{KF} / \mathrm{H}_{2} \mathrm{O}(15 \mathrm{mg} / 0.15 \mathrm{~mL})$ for $3 \mathrm{~h}$ and extracted with EtOAc $(3 \times 20 \mathrm{~mL})$. The combined organic phases were washed successively with water $(20 \mathrm{~mL})$ and brine $(20 \mathrm{~mL})$, and dried over anhydrous $\mathrm{Na}_{2} \mathrm{SO}_{4}$. After removal of the solvent, the crude product was purified by chromatography to give the desired products 4 .

\section{Supporting Information}

\section{Supporting Information File 1}

Experimental procedures and compound characterization. [http://www.beilstein-journals.org/bjoc/content/ supplementary/1860-5397-7-123-S1.pdf]

\section{Acknowledgements}

We are grateful for financial support from the National Natural Science Foundation of China (Grant No. 21072057), the National Basic Research Program of China (973 Program, 2010CB126101), the Shanghai Foundation of Science and Technology (09391911800) and the Shanghai Leading Academic Discipline Project (B507).

\section{References}

1. Qiu, X.; Meng, W.; Qing, F. Tetrahedron 2004, 60, 6711-6745. doi:10.1016/j.tet.2004.05.051

2. Jäckel, C.; Koksch, B. Eur. J. Org. Chem. 2005, 4483-4503. doi:10.1002/ejoc.200500205 
3. Meng, H.; Kumar, K. J. Am. Chem. Soc. 2007, 129, 15615-15622. doi:10.1021/ja075373f

4. Couve-Bonnaire, S.; Cahard, D.; Pannecoucke, X. Org. Biomol. Chem. 2007, 5, 1151-1157. doi:10.1039/b701559c

5. Mlostoń, G.; Obijalska, E.; Heimgartner, H. J. Fluorine Chem. 2010, 131, 829-843. doi:10.1016/j.jfluchem.2010.05.014

6. Zanda, M. New J. Chem. 2004, 28, 1401-1411. doi:10.1039/B405955G

7. Giménez, D.; Andreu, C.; del Olmo, M.; Varea, T.; Diaz, D.; Asensio, G. Bioorg. Med. Chem. 2006, 14, 6971-6978. doi:10.1016/j.bmc.2006.06.027

8. Olimpieri, F.; Tambaro, S.; Fustero, S.; Lazzari, P.; Sanchez-Roselló, M.; Pani, L.; Volonterio, A.; Zanda, M. Bioorg. Med. Chem. Lett. 2009, 19, 4715-4719. doi:10.1016/j.bmcl.2009.06.064

9. Kitamoto, T.; Marubayashi, S.; Yamazaki, T. Tetrahedron 2008, 64, 1888-1894. doi:10.1016/j.tet.2007.11.085

10. Goure, W. F.; Leschinsky, K. L.; Wratten, S. J.; Chupp, J. P. J. Agric. Food Chem. 1991, 39, 981-986. doi:10.1021/jf00005a036

11. Ojima, I.; Lin, S.; Slater, J. C.; Wang, T.; Pera, P.; Bernacki, R. J.; Ferlini, C.; Scambia, G. Bioorg. Med. Chem. 2000, 8, 1619-1628. doi:10.1016/S0968-0896(00)00093-6

12. Ferreira, S. B.; Costa, M. S.; Boechat, N.; Bezerra, R. J. S.; Genestra, M. S.; Canto-Cavalheiro, M. M.; Kover, W. B.; Ferreira, V. F. Eur. J. Med. Chem. 2007, 42, 1388-1395. doi:10.1016/j.ejmech.2007.02.020

13. Erickson, J. A.; McLoughlin, J. I. J. Org. Chem. 1995, 60, 1626-1631. doi:10.1021/jo00111a021

14. Formicola, L.; Maréchal, X.; Basse, N.; Bouvier-Durand, M.; Bonnet-Delpon, D.; Milcent, T.; Reboud-Ravaux, M.; Ongeri, S Bioorg. Med. Chem. Lett. 2009, 19, 83-86. doi:10.1016/j.bmcl.2008.11.012

15. Fustero, S.; Chiva, G.; Piera, J.; Sanz-Cervera, J. F.; Volonterio, A.; Zanda, M.; Ramirez de Arellano, C. J. Org. Chem. 2009, 74, 3122-3132. doi:10.1021/jo9001867

16. Peng, W.; Zhao, J.; He, P.; Zhu, S. Synlett 2006, 296-300. doi:10.1055/s-2006-926225

17. Li, G.; van der Donk, W. A. Org. Lett. 2007, 9, 41-44. doi:10.1021/ol062401a

18. Bigotti, S.; Meille, S. V.; Volonterio, A.; Zanda, M. J. Fluorine Chem. 2008, 129, 767-774. doi:10.1016/j.jluchem.2008.06.018

19. Bock, M. G.; Feng, D.; Kuduk, S. Aminocyclopropanecarboxamide derivatives as bradykinin antagonists. Patent WO/2005/085198, Sept 15, 2005

20. Bertinato, P.; Maddux, T. M. Microsomal triglyceride transfer protein inhibitors. Patent WO/2004/056775, July 8, 2004.

21. Dömling, A. Chem. Rev. 2006, 106, 17-89. doi:10.1021/cr0505728

22. Shibata, N.; Das, B. K.; Takeuchi, Y. J. Chem. Soc., Perkin Trans. 1 2000, 4234-4236. doi:10.1039/b007455।

23. Gouge, V.; Jubault, P.; Quirion, J.-C. Tetrahedron Lett. 2004, 45 , 773-776. doi:10.1016/j.tetlet.2003.11.019

24. Gulevich, A. V.; Shevchenko, N. E.; Balenkova, E. S.; Röschenthaler, G.-V.; Nenajdenko, V. G. Tetrahedron 2008, 64, 11706-11712. doi:10.1016/j.tet.2008.10.004

25. Wu, J.; Cao, S. Curr. Org. Chem. 2009, 13, 1791-1804. doi:10.2174/138527209789630460

26. Liu, N.; Cao, S.; Shen, L.; Wu, J.; Yu, J.; Zhang, J.; Li, H.; Qian, X. Tetrahedron Lett. 2009, 50, 1982-1985.

doi:10.1016/j.tetlet.2009.02.056
27. Wu, J.; Cao, S.; Liu, N.; Shen, L.; Yu, J.; Zhang, J.; Li, H.; Qian, X. Org. Biomol. Chem. 2010, 8, 2386-2391. doi:10.1039/c000835d

28. Li, H.; Yu, J.; Cao, S.; Shen, L.; Wu, M.; Cheng, J.; Qian, X. Sci. China, Ser. B: Chem. 2010, 53, 1509-1513. doi:10.1007/s11426-010-4005-0

29. Wu, M.; Yu, J.; Zhao, W.; Wu, J.; Cao, S. J. Fluorine Chem. 2011, 132 155-159. doi:10.1016/j.jfluchem.2010.12.010

30. Zhang, J.; Wu, J.; Shen, L.; Jin, G.; Cao, S. Adv. Synth. Catal. 2011, 353, 580-584. doi:10.1002/adsc.201000791

31. Bouma, M.; Masson, G.; Zhu, J. J. Org. Chem. 2010, 75, 2748-2751. doi:10.1021/j0100302y

32. Eto, H.; Kaneko, Y.; Takeda, S.; Tokizawa, M.; Sato, S.; Yoshida, K.; Namiki, S.; Ogawa, M.; Maebashi, K.; Ishida, K.; Matsumoto, M.; Asaoka, T. Chem. Pharm. Bull. 2001, 49, 173-182. doi:10.1248/cpb.49.173

\section{License and Terms}

This is an Open Access article under the terms of the Creative Commons Attribution License

(http://creativecommons.org/licenses/by/2.0), which permits unrestricted use, distribution, and reproduction in any medium, provided the original work is properly cited.

The license is subject to the Beilstein Journal of Organic Chemistry terms and conditions:

(http://www.beilstein-journals.org/bjoc)

The definitive version of this article is the electronic one which can be found at: doi:10.3762/bjoc. 7.123 